Acta bot. bras. I(2):143-153 (1988) supl.

\title{
CONTRIBUIÇÃO AO CONHECIMENTO DA ANATOMIA FOLIAR DE ESPÉCIES DA VEGETAÇÃO DAS DUNAS INTERIORANAS DO MUNICIPIO DE LENÇOIS-BAHIA
}

\author{
Berta Lange de Morretes (1)
}

\begin{abstract}
RESUMO - No presente trabalho é analisada a anatomia de folhas de sol, completamente expandidas de: Leucothoe oleifol (Cham) A.C. - Ericaceae, Palicourea marcgravii St. Hil. - Rubiaceae e Waltheria cinerescens St. Hil. - Sterculiaceae, provenientes de dunas interioranas. A área em questão, representa zona de transição entre cerrado e floresta. Anatomicamente, as três espécies apresentam características xeromorfas, tais como: células da epiderme abaxial com paredes anticlinais retas ou levemente curvas, espessadas; tricomas tectores ou secretores; camadas subepidérmicas aclorofiladas; parênquima paliçádico denso; paredes das células do parênquima clorofiliano com espessamentos faveolados; bainhas-de-feixe e extensōes-de-bainha parenquimáticas, esclerenquimáticas ou compreendendo os dois tecidos. Os caracteres referidos não ocorrem simultaneamente. Palavras-chaves: Anatomia ecológica, anatomia foliar, folhas de sol e xeromorfismo foliar.
\end{abstract}

\begin{abstract}
Three inland dune species were studied in the present investigation, with regard to their leaf anatomy: Leucothoe oleifolia (Ericaceae), Palicourea marcgravï (Rubiaceae) and Waltheria cinerescens (Sterculiaceae). The ecological area in which these species line is considered to be a transition between cerrado and forest. Xeromorphic characters are seen in the three species such as: adaxial epidermis with anticlinal cell walls being thickened as well as even or slightly curved when this tissue is observed in surface view; stomata and trichomes of the non-glandular and glandular types - in great number; achlorophyllous subepidermal layers; compact palisade parenchym; cell walls with reticulate thickening in the chlorenchyma; bundle sheaths and bundle sheath extensions occuring in three types: sclerenchymatous, parenchymatous and partly parenchymatous. The mentioned characters do not occur simultaneously.
\end{abstract}

Key.words: ecological leaf anatomy, leaf anatomy, leaf xeromorphism, sun leaf.

\section{Introdução}

A importância de estudos anatômicos de espécies vegetais como um todo ou apenas uma de suas partes - que integram um ecossistema, levando-se em conta o efeito dos fatores luz, temperatura, umidade relativa, pluviosidade e solo é cada vez mais patente. (Morretes 1980).

Napp - Zinn (1984) ao fazer uma cuidacosa revisão bibliográfica de trabalhos que levam em conta a Anatomia Ecológica, chama a atenção para o fato de que na América Tropical praticamente apenas o Brasil apresenta um maior número de informações sobre a organização estrutural de espécies de alguns de seus ecossistemas, tais como: cerrado, caatinga amazônica, caatinga do nordeste, restinga e floresta pluvial. O referido autor lembra que é desejável a continuidade de estudos desta natureza a fim de que possa ser compreendido o efeito que cada um dos fatores do ambiente exerce sobre a anatomia do corpo vegetal.

Em termos de Anatomia ecológica, praticamente nada foi realizado com a vegetação das dunas interioranas que ocorrem no Município de Lençóis, encravado na região da Chapada Diamantina - Bahia.

As dunas em questão representam área de transição entre cerrado e floresta e, as numerosas espécies que integram sua vegetação apresentam uma série de características anatômicas devidas a fatores do ambiente.

(1) Departamento de Botânica Instituto de Biociências Universidade de São Paulo. Caixa Postal 11461, 05499 São Paulo - Brasil 


\section{Material e Métodos}

As espécies Leucothoe oleifolia (Cham) A.C. - Ericaceae, Palicourea marcgravii St. Hil. - Rubiaceae e Waltheria cinerescens St. Hil. - Sterculiaceae são oriundas das dunas interioranas do Município de Lençóis na Bahia.

Do material botânico foram depositadas exsicatas nos Herbários do Departamento de Botânica do Instituto de Biociências da Universidade de São Paulo (SPF) respectivamente sob ns 47.506, 47.507, 47.508 e Projeto RADAM - Brasil - Salvador, Bahia (HRB).

$\mathrm{O}$ estudo anatômico baseou-se em folhas de sol, completamente expandidas, provenientes do quarto nó. Os cortes analisados foram obtidos do terço médio da folha.

Os segmentos da lâmina foliar foram fixados em etanol a 70\% (Jensen 1962) e Craf II (Sass 1951), desidratados em série alcoólica etflica, infiltrados e incluidos em parafina. Do material incluido foram feitos cortes seriados paradérmicos e transversais, variando a espessura dos mesmos de $8-13$ um.

Na confecção de lâminas permanentes foram empregados os seguintes processos de dupla coloração: "Fast - green" - Safranina (Sass 1951), Hematoxilina Delafield - Eosina (Johansen 1940) e Orange G - Violeta de cristal (Strasburger 1913).

Como reagente, para revelar paredes celulósicas ou lignificadas, foi empregado o cloreto de zinco iodado, segundo técnica de Strasburger (1913). Paredes cutinizadas ou suberizadas foram evidenciadas com Sudan IV de acordo com Foster (1949). Taninos foram reconhecidos pelo emprego de cloreto férrico a 10\% (Johansen 1940).

Os desenhos foram realizados com o auxnio da câmara-clara, tendo a escala que os acompanha sido projetada nas mesmas condições ópticas.

\section{Resultados}

Leucothoe oleifolia apresenta folhas hipoestomáticas. As células da epiderme adaxial, em vista frontal são poliédricas, apresentando paredes anticlinais geralmente retas e espessadas (Fig. 1). As células da epiderme abaxial, também poliédricas, são menores, possuindo paredes anticlinais mais delgadas. Os estômatos são circundados por cinco ou seis células, pertencendo ao tipo anomocítico. Ao nível do complexo estomático a cutícula e seus estratos formam uma crista, em conseqüência da qual os estômatos situam-se numa câmara. (Fig. 2). As paredes periclinais externa e interna das células epidérmicas são espessadas e adquirem a mesma coloração das fibras e elementos de vaso, quando tratados pela Safranina.

As figuras 3, 4 e 5 mostram a organização do aparelho estomático. As paredes periclinais das células estomáticas são espessadas, reduzindo o lume celular em sua região mediana; na região polar dos estômatos estes espessamentos inexistem. As células epidérmicas circunjacentes ultrapassam as células estomáticas ao nível da câmara subestomática.

Leucothoe oleifolia (Cham.) A.C.

Fig. 1 - Epiderme adaxial em vista frontal; Fig. 2 - Epiderme abaxial em vista frontal; Fig. 3 - Corte transversal mediano do complexo extomático, sendo visível o espessamento das paredes periclinais das células estomáticas; Fig. 4 - Corte transversal do complexo estomático ser. jo visíveis uma célula estomática seccionada segundo o seu maior eixo e a câmara formada pela cutícula e estratos cuticulares; Fig. 5 - Corte transversal do complexo estomático ao nível da região polar do estômato; Fig. 6 - Epiderme adaxial em vista frontal, revelando a densidade das células do parênquima paliçádico; Fig. 7 - Corte transversal da lâmina foliar mostrando a disposição das células do parênquima lacunoso; Fig. 8 - Corte transversal da lâmina foliar. São visíveis: um feixe vascular de médio porte com suas bainhas parenquimática e esclerenquimática e as células do parênquima lacunoso com espessamentos faveolados; Fig. 9 - Corte transversai ao nível do bordo foliar sendo visíveis os idioblastos epidérmicos, um estómato e um pequeno feixe vascular. 

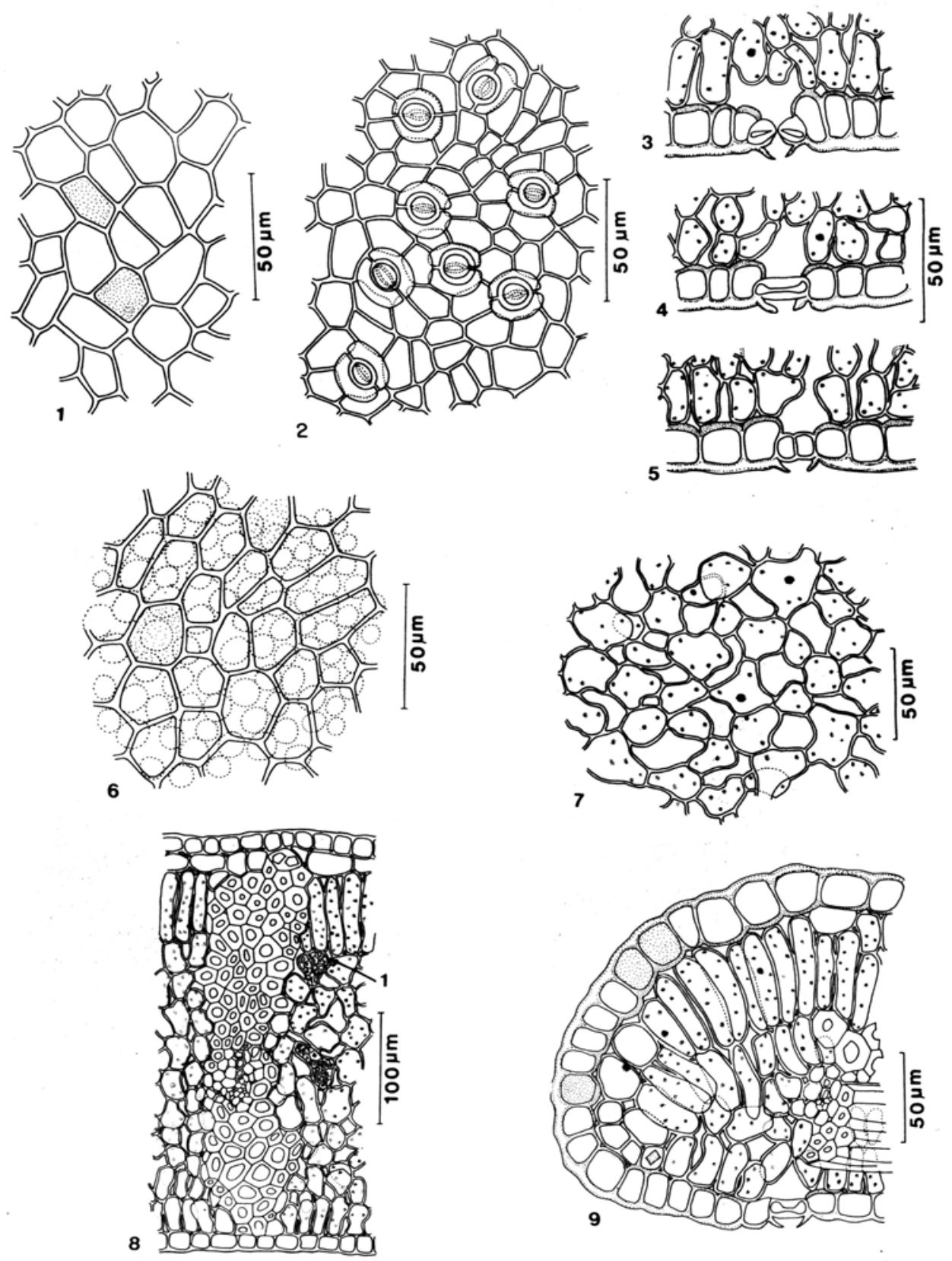

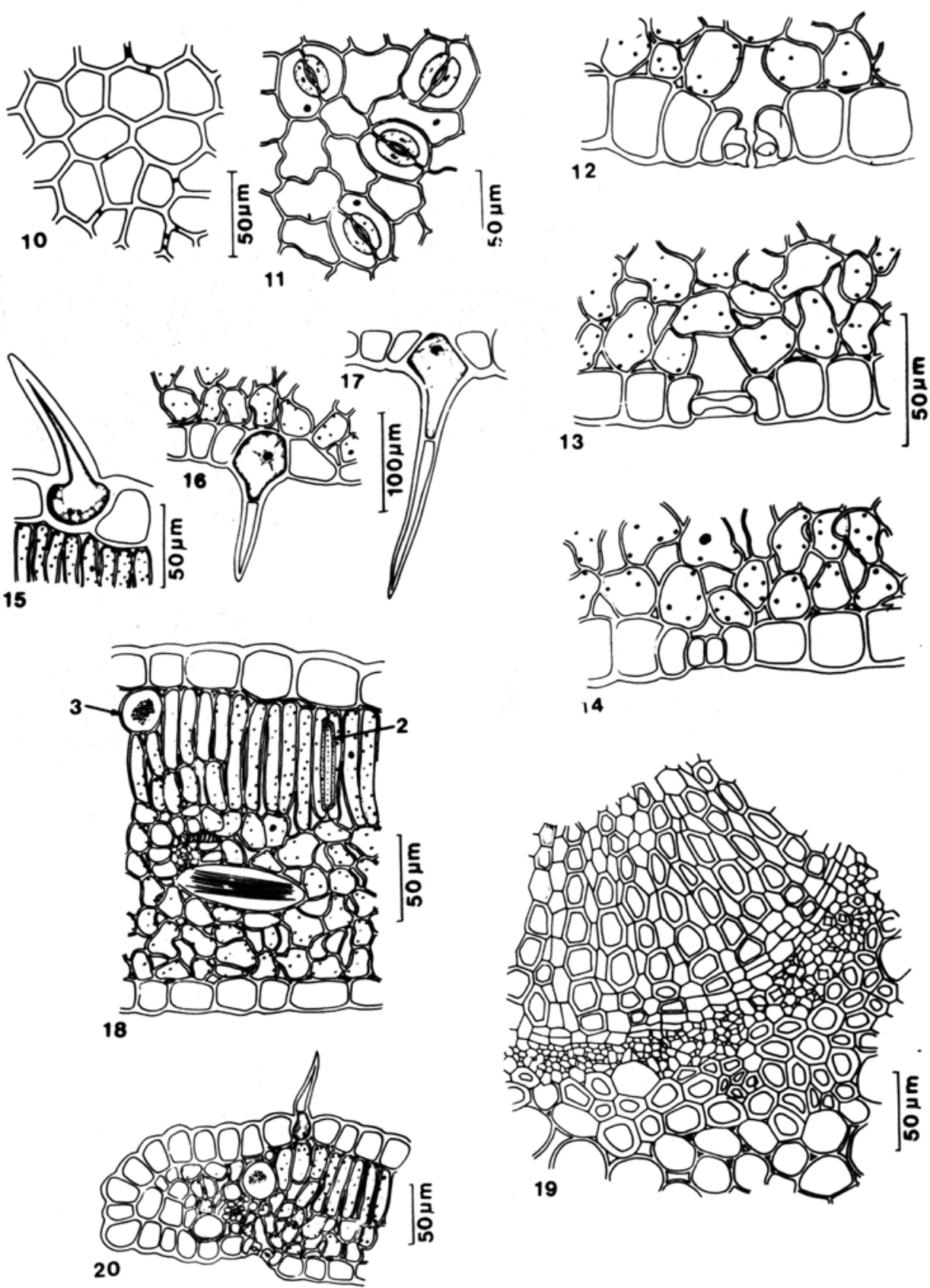
A figura 6 revela a densidade da disposiçăc das células do parênquima paliçádico, bem como a relação entre o número destas células e o das células epidérmicas adaxiais.

O parênquima lacunoso é formado por células irregulares que deixam entre si espaços de diferentes dimensões (Fig. 7).

A secção transversal da lâmina foliar, ao nivel de uma nervura de médio porte encontra-se representada na figura 8 . Abaixo da epiderme adaxial ocorre um estrato de células aclorofiladas, de paredes delgadas. De espaço em espaço, nesta camada, situam-se idioblastos portadores de cristais isolados

O parênquima paliçádico é representado por um estrato de células estreitas e altas que se conectam com células coletoras. C parênquima lacunoso típico, representado por sete a oito camadas, apresenta nas paredes celulares espessamentos faveolados. A cámada parenquimática em contacto com a epiderme abaxial assernelha-se ao parênquima paliçádico; no entanto, suas células sảo bem menores do que as situadas junto à epiderme adaxial (Fig. 8, seta 1).

Os feixes vasculares de médio e pequeno porte são envolvidos por uma bainha parenquimática, cujas células apresentam paredes delgadas. Ao redor desta bainha situa-se esclerênquima que forma extensões-de-bainha que atingem as duas epidermes.

A organização do bordo foliar encontra-se representada na figura 9. Também aqui, as células da epiderme apresentam paredes periclinais espessadas e lignificadas; estômatos estào presentes. Le espaço ern espaço idioblastos entremeiam-se às células epidérmicas. Ao nível do bordo, em posição sub-epidérmica, ocorre um grupo de células de parênquima aciorofilado. Na região, podem ser encontrados idioblastos contendo cristais isolados. Um feixe vascular de pequeno porte, situa-se nas proximidades do bordo.

Palicourea marcgravii possui folhas hipoestomáticas. A epiderme adaxiai, em vista frontal, apresenta células poliédricas de paredes anticlinais espessadas, retas ou levemente curvas (Fig. 10). As células da epiderme abaxial, vistas frontaimente, revelam paredes anticlinais sinuosas e mais delgadas do que as da epiderme adaxial. Os estômatos pertencem ao tipo paracítico (Fig. 11). A organização do aparelho estomático é visível nas figuras 12,13 e 14. As paredes periclinais interna e externa são espessadas, condicionando redução do lume celular na regiāo mediana da célula estomática (Figs. 12 e 13). Os espessamentos parietais não ocorrem ao nivel da regiäo polar do estômato (Fig. 14). As células anexas ultrapassam as estomáticas ao nível da câmara subestomática.

As epidermes ad e abaxial são providas de tricomas tectores unicelulares ou unisseriados, que apresentam paredes espessadas especiaimente na regiāo apical. A cutícula reveste os tricomas em questão. Os tricomas unicelulares são vivos e, os pluricelulares unisseriados, apresentam geralmente a célula terminal morta (Figs. 15, 16 e 17). Na secção transversal das lâmina foliar, verifica-se que a cutícula e os estratos cuticulares são mais espessos na epiderme adaxial (Fig. 18).

\section{Palicourea marcgravii St. Hil.}

Fig. 10 - Epiderme adaxial em vista frontal; Fig. 11 - Epiderme abaxial em vista frontal; Fig. 12 - Corte transversal mediano do complexo estomático. Jã̄ visíveis os espessamentos das paredes periclinais das células estomáticas e a projeção das células anexas na câmara subestomática; Fig. 13 - Corte transversal do complexo estomático sendo visível uma célula estomática seccionada segundo o seu maior eixo; Fig. 14 - Corte transversal do complexo estomático realizado ao nível da regiâo polar do estômato; Fig. 15 - Corte transversal da lâmina foliar revelando um tricoma unicelular ao nível da face adaxial da folha; Fig. 16 - Corte transversal da lâmina foliar mostrando ao nível da epiderme abaxial um tricoma bicelular curto; Fig. 17 - Epiderme abaxial provida de um tricoma bicelular Inngo; Fig. 18 - Corte transversal da lâmina foliar. Além do clorênquima são visíveis os idioblastos contendo ráfides e o idioblasto provido de um cristal estitóide; Fig. 19 - Corte transversal da nervura mediana da totha, revelando a presença de um câmbio funcional; Fig. 20 - Corte transversal da lámina foliar ao nível do bordo. 
No mesofilo, o parênquima paliçádico é representado por um estrato de células altas e estreitas relacionadas com células coletoras. O parênquima lacunoso compreende cinco a seis camadas de células irregulares e de dimensões variadas.

No clorênquima situam-se idioblastos portadores de tanino, ráfides ou cristais estilóides. Os idioblastos contendo tanino ou cristais estilóides situam-se paralelamente às células do parênquima paliçádico (Fig. 18, seta 2). Os contendo ráfides, situados abaixo da epiderme adaxial, ocupam uma posição perpendicular ao maior eixo da célula paliçádica (Fig. 18, seta 3).

Os idioblastos contendo ráfides também ocorrem no parênquima lacunoso, situandose freqüentes vezes, junto aos feixes vasculares.

Os feixes vasculares de médio e pequeno porte são envolvidos por uma bainha parenquimática aclorofilada; ao nível do floema, ocorre um grupo de fibras (Fig. 18).

A nervura central é proeminente em ambas as faces da lâmina foliar. Um pormenor de sua organização encontra-se registrado na figura 19. Entre o xilema e o floema situa-se um câmbio ativo, pois são visíveis elementos condutores jovens, tanto ao nível do xilema como do floema. O floema é envolvido por uma calota de fibras.

A figura 20 representa a estrutura do bordo foliar. Em posição subepidérmica situase um grupo de células parenquimáticas aclorofiladas. Na região ocorrem estômatos, idioblastos portadores de tanino ou ráfides, um feixe vascular de pequeno porte e tricomas unisseriados.

Waltheria cinerescens apresenta folhas anfi-estomáticas, ocorrendo menor número de estômatos na epiderme adaxial. As células epidérmicas são poligonais em vista frontal, apresentando formato e dimensöes diversos. As paredes anticlinais em ambas as epidermes podem ser retas ou levemente curvas, sendo as da epiderme adaxial mais espessadas. Os estômatos da epiderme adaxial são circundados por três ou quatro células que se assemelham às demais células epidérmicas, ficando assim caracterizado o estômato anomocítico (Fig. 21). Os estômatos da epiderme abaxial são morfologicamente paracíticos ou anomocíticos. As células epidérmicas de modo geral, possuem paredes anticlinais um pouco mais delgadas do que as da epiderme adaxial (Fig. 22).

O complexo estomático situa-se um pouco acima das demais células epidérmicas. As paredes periclinais externa e interna da célula estomática são levemente espessadas. As células epidérmicas adjacentes ultrapassam as estomáticas ao nível da câmara subestomática. Esta, é estreita, atingindo geralmente o segundo estrato do parênquima paliçádico (Figs. 23, 24, 25 e 26).

A disposição das células do parênquima paliçádico em relação às células epidérmicas encontra-se registrada nas figuras 27 e 28 . Na face adaxial da lâmina foliar a disposição é mais densa.

Waltheria cinerescens St. Hil.

Fig. 21 - Epiderme adaxial em vista frontal; Fig. 22 - Epiderme abaxial em vista frontal. São visíveis estômatos anornocíticos e paracfticos; Fig. 23 - Corte transversal mediano do complexo estomático sendo visível que os estômatos situam-se um pouco acima das células epidérmiras; Fig. 24 - Corte transversal do complexo estomático ao nível da regiăo polar do estômato; Fig. 25 - Curte transversal do complexo estomático revelando uma célula estomática seccionada segundo o seu maior eixo; Fig. 26 - Corte transversal do complexo estomático revelando uma célula estomática ao nível da epidem abaxial; Fig. 27 - Epiderme adaxial mostrando a disposição densa das células do parênquima paliçádico; Fig. 28 - Epiderme abaxial mostrando a disposiçāo menos densa das células do parênquima paliçádico; Fig. 29 - Corte transversal da lâmina foliar. Sáo visiveis os tricomas secretores capitados, um feixe vascular de médio porte com sua bainha parenquimática e a organização do clorênquima; Fig. 30 - Corte transversal da lâmina foliar revelando um tricoma secretor na epiderme abaxial; Fig. 31 - Corte transversal da lâmina foliar ao nivel do bordo. São visíveis um estômato, um feixe vascular de pequeno porte com sua extensão de bainha e o clorênquima ao nível da epiderme. 


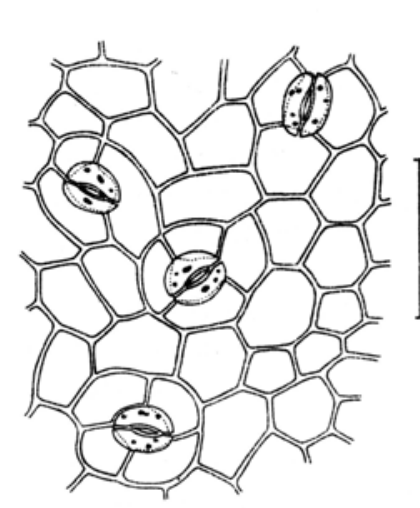

21
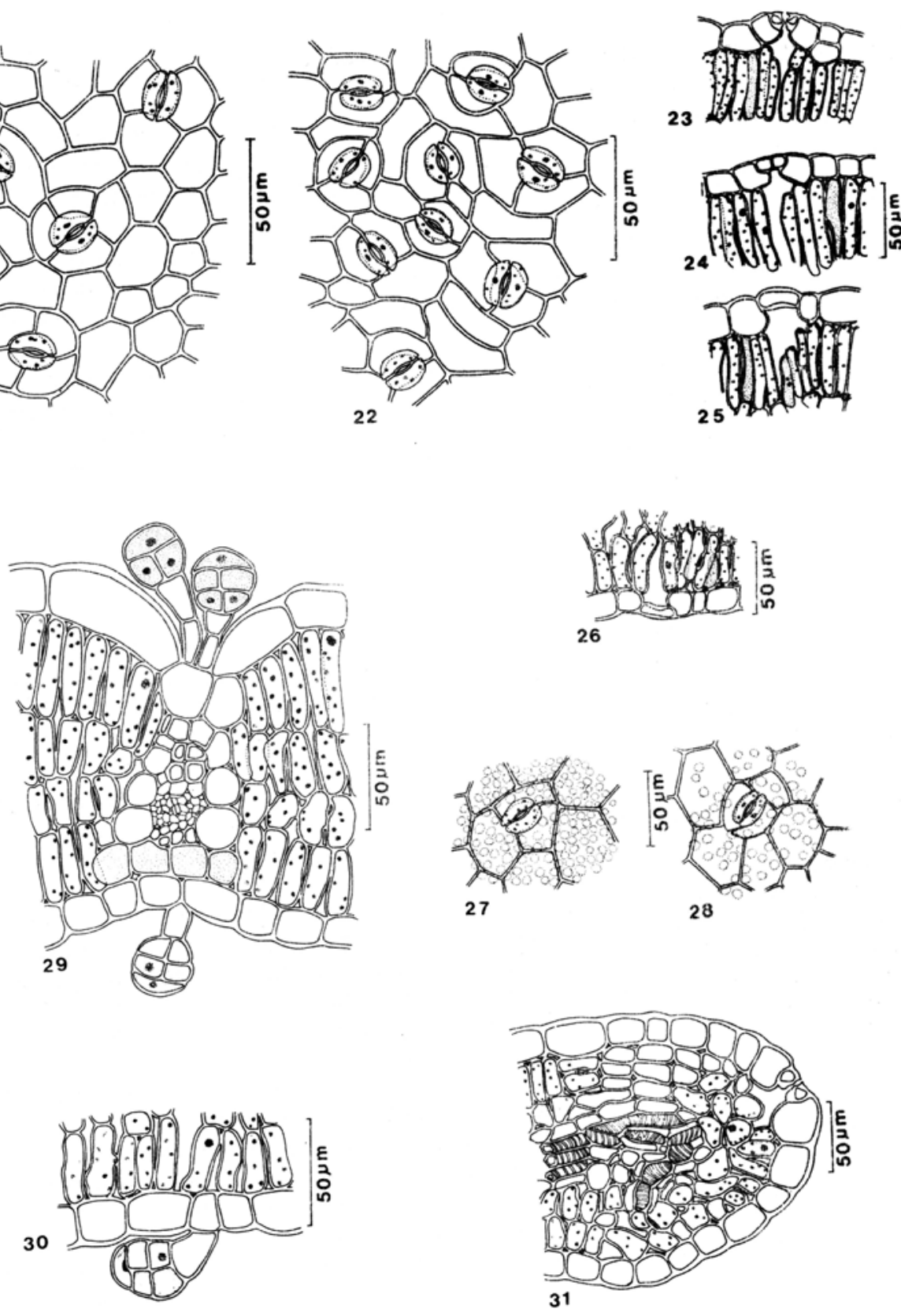
A secção transversal da lâmina foliar mostra que a epiderme adaxial apresenta cuttcula e estratos cuticulares mais espessos do que os da epiderme abaxial. Tricomas secretores ocorrem em ambas as faces da folha. Estes tricomas podem apresentar-se isolados ou em grupos. O "caput" é constituido por células que apresentam citoplasma denso e núcleo grande. Uma cutícula delgada envolve o pedicelo e as células secretoras (Figs. 29 e 30). O mesofilo é constituido por parênquima paliçádico típico junto às epidermes ad e abaxial, não existindo um parênquima lacunoso bem caracterizado. Em algumas regiões do mesofilo são visíveis células coletoras sobrepostas, bem como idioblastos portadores de tanino.

Os feixes vasculares de médio e pequeno porte são envolvidos por uma bainha de natureza parenquimática, destituida de cloroplastídios. As extensões-de-bainha geralmnte atingem ambas as epidermes. Entre o xilema e o floema situam-se células parenquimáticas (Fig. 29).

A figura 30 representa a organização do bordo da folha. Os estômatos que se situam nesta região apresentam a mesma organização dos que são encontrados em outras regiōes da lâmina foliar. $O$ parênquima clorofiliano atinge a epiderme, não ocorrendo esclerênquima ou colênquima subepidérmico. Um pequeno feixe vascular situa-se ao nível do bordo foliar.

\section{Discussão}

Dentre os pesquisadores que reuniram - em obras maiores - dados sobre a anatomia foliar ou anatomia foliar ecológica, lembramos De Bary (1877), Solereder (1908), Goebel (1913), Haberlandt (1918), Eames e MacDaniels (1947), Metcalfe e Chalk (1950, 1979, 1983), Meyer (1962), Esau (1965, 1977), Napp-Zinn (1973, 1974, 1984), Cutter (1978) e Fahn (1983).

Cabe a Napp-Zinn (1984) o mérito de ter realizado a mais cuidadosa revisão crítica da bibliografia referente à Anatomia Ecológica da folha das Angiospermas, lembrando que já em 1747 Guettard estudou espécies levando em conta as adaptações ao ambiente, especialmente aquático.

Muitas das informações sobre a anatomia foliar são obtidas a partir de material herborizado, fato que pode conduzir a uma série de erros de interpretação. Scott (1889) enfatiza em seu trabalho, ser diff́cil tirar boas conclusões examinando-se apenas algumas secções obtidas a partir de folhas secas oriundas de herbários. Metcalfe e Chalk (1979), apesar de também apresentarem muitas vezes informaçőes obtidas a partir de exsicatas de herbário, endossam inteiramente a opinião de Scott.

Recentemente, Morretes e Venturelli (1985) demonstraram que as verrugas ou lenticelas descritas em folhas de Tripodanthus acutifolius (R. £ P.) Tiegh., - a partir de material herborizado - nada mais são do que um artefato resultante do dessecamento.

Acreditamos ser importante que investigações de cunho anatômico não se baseiem apenas em material herborizado, mas também levem em conta material vivo ou fixado, pois com estes cuidados uma série de problemas teria solução.

Da análise bibliográfica verificou-se que existem referências aos gêneros Leucothoe, Palicourea e Waltheria e a aspectos isolados de Leucothoe oleifolia (Solereder 1908 Metcalfe \& Chalk 1950, 1979, 1983 Napp-Zinn 1973, 1974).

Solereder (1908), Metcalfe e Chalk (1979) e Napp-Zinn (1984) lembram que o formato das células epidérmicas e $\mathrm{o}$ aspecto de suas paredes anticlinais e periclinais constituem caracter relevante em Anatomia aplicada à Taxonomia e à Ecologia. Assim, células com paredes anticlinais e/ou periclinais espessadas ocorrem com freqüência em espécies 
provenientes de regiōes áridas ou sujeitas à "stress" hidrico. Leucothoe oleifolia, Palicourea marcgravii e Waltheria cinerescens apresentam epidermes adaxiais com paredes anticlinais espessadas, sendo a diferença de espessamento entre as epidermes ad e abaxial pequena em Leucothoe e Waltheria porém significativa em Palicourea. As três espécies revelam paredes periclinais espessadas, especialmente Le ucothoe ole ifolia. Outras características da epiderme de espécies submetidas a "stress" hídrico, como cutícula e estratos cuticulares espessos e estômatos em depressỏes foram registradas em Leucothoe e Palicourea. Os estômatos de Leucothoe localizam-se em pequenas câmaras formadas às expensas da cutícula e seus estratos. Os complexos estomáticos de Waltheria situamse acima do nível das demais células epidérmicas, fato registrado por Ferri (1955) para algumas espécies da caatinga nordestina de Paulo Afonso. As espécies analisadas por este autor apresentam um mecanismo rápido de abertura e fechamento dos estomatos. Para contrapor estes dois dados, torna-se necessário conhecer o comportamento estomático de Waltheria. A epiderme de Waltheria também possui cutícula e estratos cuticulares espessados. Hull et al. (1975) e Blackmann et al. (1980) verificaram que a espessura da cutícula e seus estratos são influenciados pelos fatores ambientais.

Examinando-se as publicações existentes que referem a presença ou ausência de tricomas foliares, verifica-se que grande parte dos pesquisadores empregou material não padronizado. Nó de proveniência dạ folha, grau de expansão da lâmina foliar, folhas de sol ou de sombra e época em que for teita a coleta não constam das descriçōes, na maioria dos casos. Schimper (1903), Warming (1909) e Haberlandt (1918) lembram que a presença de tricomas é caracter comum em espécies de regiōes áridas ou alpinas e que, nos casos de espécies que ocorrem também em "habitat" mésico o número de tricomas decresce ou as folhas tornam-se glabras. Napp-Zinn (1984) revela que pesquisas feitas em material não padronizado mostram que as folhas podem apresentar grandes variações estruturais em função dos caracteres acima referidos. Assim Harley e Simons (1986), descrevem a folha de Palicourea marcgravii como glabra, sem referir se a folha era completamente expandida, de sol ou de sombra e data da coleta.

A análise anatômica de folhas cie sol, completamente expandidas, provenientes do quarto nó, coletadas em julho de 1986 revelou a presença de tricomas unicelulares e pluricelulares unisseriados, em ambas as f́aces da lâmina foliar. Quanto aos tricomas de Waltheria, Solereder (1908) refere sua presença no gênero sem contudo descrevê-los. Os tricomas em $W$. cinerescens são pluricelulares pertencendo ao tipo dois da classificação dos iricomas secretores, estabelecidas por Solereder (1908) que são caracterizados pela regiäo secretora multicelular compreendendo paredes anticlinais e periclinais. Ocorrem em ambas as faces da lâmina foliar e situam-se em depressões da epiderme. A partir de 1970 foram retomados estudos dos tricomas tectores e secretores levando-se em conta aspectos relacionados com a histoquímica, ecologia, ecofisiologia e ultra-estrutura (Benke 1384, Ehleringer 1984, Peterson \& Vermeer 1984). Pesquisas desta natureza faltam praticamente em relaçāo às espécies brasileiras.

A presença de camadas subepidérmicas aclorofiladas em xeromorfas ou xerófitas é referida por uma série de pesquisadores, dentre os quais referimos De Bary (1877), Solereder (1908), Haberiandt (1918), Eames e MacDaniels (1947), Metcalfe e Chalk (1950, 1979, 1983), Morretes e Ferri (1959, 1972), Napp-Zinn (1973, 1974, 1984) e Morretes (1980).

Das três espécies analisadas, apenas Leucothoe apresenta estrato subepidérmico aclorofilado. Areschoug (1882), Solereder (1908), Metcalfe e Chalk (1979, 1983), Fahn (1983) e Napp-Zinn (1984) lembram que entre os caracteres de xerófitas ou xeromorfas, deve ser referida a existência de folhas isobilaterais ou a tendência a esta organização do mesofilo. Solereder (1908) ao descrever a estrutura foliar dos representantes da familia Sterculiaceae, informa que Dumont (1887) afirma que raras vezes as folhas das Sterculia- 
ceą são ısobilateraıs, cıtando como exemplo Reevesia. O mesofio de Walıherua cıncresc' 'nss é constıtuido apenas por parènquima palıçádıco, sendo as células parenquimátıcas em contacto com a epiderme abaxial menores.

Leucothose oleifolua revela tendência à ısobılateralıdade pors o parênquima clorofilıanc em contacto com a epıoerme abaxıal nāo é lacunoso típico. Esau $(1965,1977)$ lembra quє dierenças estruturaıs estāo relacıonadas com adaptaçōes evolutıvas aos díerentes am. Dientes.

vesque (1886) de acordo com Solereder (1908) for o pnmeiro a descrever espessamentos reticulados em células do parênquima clorofiliano de espécies sujertas ao fenómeno de "stress" hidrico.

Leucothce oleifolia apresenta espessamentos faveolados - uma vanaçào deste tıpc. de espessamento - especıalmente nas cétulas do parênquıma lacunosc.

Solereder (1908), ao tazer a anáhse da organızaçảo da lámına tolıar das Rubıaceae, crıstalíteros podem constutuır caracter de importâncıa taxonómica.

Solereder (1908) ao tazer a anáhse da organızação da lâmına folıar das Rubıaceae, retere a presença de ráfides e cristaıs estikıdes no género Palicourea.

Palicourea marcgravi apresenta crıstass estibódes no parênquima palıçádıco, em posıção paraiela ao maır eixo das cétulas em palıçada. Os idıoblastos contendo ráfıdes sıtuam-se no parênquıma palıçádıco, ımedıatamente abaıxo da epıderme, e, no parênquıma lacunoso ou junto à bainha-de-feixe.

O bordo foliar das três espécies analısadas não revela a presença de colènquıma ou: esclerênquima, fato relativamente comum em xerótitas ou xeromortas.

Das três espécies, apenas Leucothoe apresenta os feixes vasculares de médıo porte providos de duas calotas de fibras. Em Palicourea marcgranit as fibras envolvem apenas o floema.

As espécies onundas da caatinga amazónica, estudadas por Morretes e Ferri (1972) e Morretes (1980), sáo mas nicas em elementos mecánicos do que Leiıcothoc oleitolıa. Palucourea marcgravii e Waltheria cinerescens, que também crescem sobre solo arenoso.

\section{Referências Blbliograficas}

ARESCHOL'G. F.W.C. 1882. Der Einfluss des Klımas auf die Organısation der Pflanzen, insbesonderen auf die anatomische Structur der Blattorgne. Bot. Jahrh., 2:511-520

BARY, A. DE. 1877. Vergleichende Anatcimie der Vegetationsorgane der Phunerogume und Farne. Verla: Wilhelm Engelmann, Leipzig.

BENKE, H.D. 1984 - Plant trichomes - structure and ultrastructure: general termınology, taxonomic ap. plications and aspects of trichome-bacteria interaction in leat ups of Dwoscorea. In E. Kodriguez. P. Healey e I. Mehta (ed). - Biology and Chernustry of Plant Trichomes. Plenum Press. New liorh.

BLACKMANN, C.A., HULL, H.M. \& HOSHAW.R.W. 1980. Cuticular ultrastructure of Prosopes velut! na and Acacra greggii leaflets. Bot. Ga: 141: 1-8.

CL'TTER, E.G. 1978. Plant Antomy. Part 1, 2 ed. Edward Arnold. London

EAMES. A.J. \& MACDANIELS, L.H. 1947. An Introduction to Plant Antomy. 2 ed. Macgraw-Hill Comp New York.

EHLERINGER, J. 1984. Ecology and Ecophysiology of leaf pubescens in North American Desert plants In E. Rodriguez, P. Healey e I. Mehta (eds.). - Biology and Chemistry of Plant Trichomes. Plenum Press New York.

ESAL: K. 1905. Plant Anatomy. 2 ed. John Wikey and Sons. New York.

ESAU. K. 1977. Antomy of Seed Plants. 2 ed. John Wiley and Sons. New York

FAHN. A. 1983. Plant Anatomy. 3 ed. Pergamon Press. Ox ford

FERRI, M.G. 1955. Contribuiçiso wo conhecimento da ecologla do cerrado e da castinga. Bobn Far. Fil. Ciénc. Letr.. Univ. S. Paulo 19.5. Boddinica 12: 5- 170

FOSTER, A.S. 1949. Practical Plant Antomy. 2 ed. Van Nostrand Company. Nicu-York.

GOEBEL, K. 1913. Ornanographie der Pfianzen. 2 ed. 4 vol. G. Fischer. Jena.

HA BERLA NDT, G. 1918. Physiologische Pflanzenanatomie. S ed. Verlag von Wilhelm Engelmann. LeipZiE.

HAREEY, R.M. I SIMIMONS, N.A. 1986. Flonda of Afucugé Chnpada Diamantina. Bahia. Brasil. Kuyal Botanic Gardens Kew.

HARTOG. K.M. E BAAS, P. 1978. Epidermal characters of the Celastraceac "sensulato". Arta Bor. Ne. er.. 27: 355-388. 
HULL, H.M., MORTON, H.L. £ WARRIER, I.R. 1975. Environmental influences on cuticle development and resultant foliar penetration. Bot. Rev., 41:421-452.

JENSEN, W.A. 1962. Botanical Histochemistry: principles and practices. W.H. Freeman and Company. San Francisco.

JOHANSEN, D.A. 1940. Plant Microtechnique. McGraw-Hill Book Company Inc. New York.

METCALFE, C.R. £ CHALK, L. 1950. Anatomy of the Dicotyledons. 2 vols. Clarendon Press. Oxford.

METCALFE, C.R. £ CHALK, L. 1979. Anatomy of the Dicotyledons. 2 ed. Clarendons Press. Oxford. vol. 1.

METCALFE, C.R. £ CHALK, L. 1983. Anatomy of the Dicotyledons 2 ed. Clarendon Press. Oxford. vol. 2.

MEYER, F.J. 1962. Das trophische Parenchym - A. Assimilationsgewebe. In: W. Zimmermann $£$ P.G. Ozenda (eds.) Handbuch der Pflanzenanatomie Bd IV Teil 7A. Gebrüder Borntraeger. Berlin.

MORRETES, B.L. de. 1980. Contribuição ao conhecimento da anatomia ecológica de plantas do cerrado de Emas-SP e da caatinga amazônica do Km 62 da rodovia BR 174. Tese de Livredocência, Univ. S.Paulo.

MORRETES, B.L. de $£$ FERRI, M.G. 1959. Contribuição ao estudo da anatomia das folhas de plantas do cerrado I. Bolm Fac. Fil. Ciênc. Letr. Univ. S. Paulo 243, Botânica, 16: 7-70.

MORRETES, B.L. de £ FERRI, M.G. 1972. Contribuição ao conhecimento da anatomia de folhas de plantas de uma caatinga do Rio Negro (Amazonas). Revta Biol. Lisboa, 78 (1/4): 97-122.

MORRETES, B.L. de $£$ VENTURELLI, M. 1985. Ocorrência de “lenticelas" em folhas de Tripodanthus acutifolius (R. £ P.) Tiegh. (Loranthaceae). Revta brasil. Bot., 8: 157-162.

NAPP-ZINN, K. 1973/1974. Anatomie des Blattes II. Blattanatomie der Angiospermen. In: W. Zimmermann, S. Carlquist $£$ P. Ozenda (eds.) Handbuch der Pflanzenanatomie Bd 8, Teil 1A e 2A. Gebrüder Borntraeger. Berlin.

NAPP-ZINN, K. 1984. Anatomie des Blattes II. Blattanatomie der Angiospermen. B. Experimentelle und ökologische Anatomie des Angiospermenblattes. In: H.J. Braun, S. Carlquist, P. Ozenda f I. Roth (eds.) Handbuch der Pflanzenanatomie Bd. VIII Teil 2B Gebrüder Borntraeger. Berlin.

PETERSON, R.L. $£$ VERMEER, J. 1984. Histochemistry of Trichomes. In: E. Rodriguez, P. Healey $£$ I. Mehta ed. Biology and Chemistry of Plant Trichomes. Plenum Press. New York.

PYYKKÖ, M. 1966. The leaf anatomy of East Patagonian xerophytic plants. Ann. Bot. Fenn. 3: 453-632.

SASS, J.E. 1951. Botanical microtechnique. Iowa State University Press. Ames.

SCHIMPER, A.F.W. 1903. Plant geography upon a physiological basis. Clarendon Press. Oxford.

SCOTT, D.H. 1889. On some recent progress in our knowledge of the anatomy of plants. Ann. Bot. 4: $147-161$.

SOLEREDER, H. 1908. Systematic Anatomy of the Dicotyledons. 2 vols. Clarendon Press. Oxford.

STRASBURGER, E. 1913. Das Botanische Praktikum. Verlag Gustav Fischer. Jena.

WARMING, E. 1909. Oecology of Plants. Clarendon Press. Oxford. 